\title{
HUBUNGAN KONSEP DIRI DENGAN PERILAKU MEROKOK PADA SISWA DI SMP NEGERI SATU ATAP TOYADO
}

\section{The Relationship Between Self-Concept and Smoking Behavior on Students of Satu Atap Middle School Toyado}

Agusrianto, Nirva Rantesigi

Poltekkes Kemenkes Palu

(ners.agus73@gmail.com,082347676307)

\begin{abstract}
ABSTRAK
Perilaku merokok merupakan fungsi dari lingkungan dan individu. Artinya, perilaku merokok selain disebabkan faktor-faktor dari lingkungan, juga disebabkan faktor dari dalam diri individu. Perilaku merokok pada remaja diduga terkait dengan karakter psikologis tertentu yang dimiliki yaitu konsep diri mereka sebagai remaja. Tujuan penelitian untuk mengetahui hubungan antara konsep diri dengan perilaku merokok di siswa. Desain penelitian ini menggunakan metode analitik dengan pendekatan cross-sectional study. Penelitian di SMP Negeri 1 Atap Toyado pada bulan Juni-Juli 2017. Sampel dengan teknik Simpel random sampling berjumlah 92 orang. Hasil penelitian menunjukksn 64,7\% responden dengan konsep diri tinggi dan berperilaku merokok, dan 35,3\% dan responden dengan konsep diri sedang dan berperilaku merokok. Hasil uji statistik dengan uji chisquare diperoleh nilai $\mathrm{p}=1,000(\mathrm{p}>0,05)$ tidak ada hubungan antara konsep diri dengan perilaku merokok siswa. Disarankan agar siswa lebih memperkuat wadah atau organisasi ekstrakurikuler yang terkait upaya pencegahan terhadap bahaya perilaku perilaku merokok agar para siswa tidak melalukan perilaku merokok.
\end{abstract}

Kata kunci : Konsep Diri, Perilaku, Merokok

\section{ABSTRACT}

Smoking behavior is a function of the environment and individuals. It means, besides the external factor of environment, it is also caused by internal factors that is individual. Smoking behavior in adolescents is assumed to correspond with certain psychological characteristics they have, namely their self-concept as adolescents. The purpose of this research is to determine the relationship between self-concept and smoking behavior on students. The design of this research used an analytical method with a cross-sectional study approach. This research was conducted at Satu Atap Middle School Toyado in June-July 2017. The sample of this research is 92 people selected using the Simple Random Sampling technique. The results showed that $64.7 \%$ of respondents had high selfconcept and smoking behavior, and $35.3 \%$ and respondents had a fair self-concept and smoking behavior. The results of the statistical test with the chi-square test obtained a value of $p=1,000$ ( $p$ > 0.05) which means no relationship between self-concept and students' smoking behavior. It is recommended that students can further strengthen extracurricular organizations or organizations that are related to prevention efforts against the dangers of smoking behavior so students avoid smoking behavior.

Keywords : Self-concept, behavior, smoking 


\section{PENDAHULUAN}

Merokok bagi sebagian besar masyarakat Indonesia sudah dianggap sebagai perilaku yang wajar dan menjadi bagian dari kehidupan sosial dan gaya hidup tanpa memahami resiko dan bahaya kesehatan terhadap dirinya serta masyarakat di sekitarnya. Para perokok tidak menyadari bahwa mereka terjerat dalam kondisi ketergantungan yang sangat sulit dilepaskan $^{(1)}$.

Merokok adalah perilaku orang dewasa yang paling mudah untuk ditiru dan merupakan perilaku yang paling nyata untuk menunjukan kedewasaan, perilaku tersebut ditampilkan untuk membuktikan bahwa remaja ingin diketahui keberadaannya oleh lingkungan dan orang-orang sekitarnya, mereka tak ingin dianggap anak kecil lagi. Karena pada masa ini remaja sedang dalam proses pencarian identitas diri, sehingga rasa ingin tahu mereka sangat besar untuk mencoba hal-hal yang baru seperti merokok. Mereka meniru bukan hanya dari orang-orang sekitar tetapi juga mereka tiru dari model atau iklan yang ada di berbagai media. Remaja mulai mencoba-coba untuk merokok dan dikuatkan dengan komentar dari orang-orang bahwa dengan merokok mereka terlihat gagah, lalu mereka jadi terbiasa mulai kecanduan untuk merokok. Data Riset Kesehatan Dasar menunjukkan adanya kecenderungan peningkatan prevalensi perokok usia 15 tahun ke atas setiap tahunnya, dari $34,2 \%$ pada Riskesdas 2007, menjadi $34,7 \%$ pada Riskesdas 2010 dan 36,3\% pada Riskesdas
2013. Jumlah rata-rata rokok yang dihisap oleh penduduk diatas umur 10 tahun di Indonesia, mencapai 12,3 batang atau sekitar satu bungkus per hari ${ }^{(2)}$. Berdasarkan penelitian pendahuluan sebelumnya oleh peneliti disalah satu SMP yang ada di kota poso, ditemukan bahwa prevalensi remaja yang merokok di SMP tersebut mencapai 40,3\%. Hal ini merupakan angka yang masih cukup besar dan sangat perlu menjadi perhatian kita semua.

Berdasarkan data tersebut terlihat adanya peningkatan perilaku merokok pada remaja perilaku merokok merupakan fungsi dari lingkungan dan individu. Artinya, perilaku merokok selain disebabkan faktor-faktor dari lingkungan, juga disebabkan faktor-faktor dari dalam diri individu. Perilaku merokok pada remaja diduga terkait dengan karakter psikologis tertentu yang dimiliki yaitu konsep diri mereka sebagai remaja. Penelitian ini bertujuan untuk mencari hubungan antara konsep diri dengan perilaku merokok pada siswa di SMP Negeri 1 Atap Toyado.

\section{METODE PENELITIAN}

Desain penelitian ini menggunakan metode analitik dengan pendekatan cross-sectional study. Lokasi penelitian ini di laksanakan di SMP Negeri 1 Atap Toyado pada bulan JuniJuli 2017. Sampel dengan teknik Simpel random sampling berjumlah 92 orang.

\section{HASIL}

Lima puluh sembilan responden $(64,1 \%)$ terbanyak konsep diri tinggi dan 33 responden $(35,9 \%)$ terendah konsep diri sedang. dari total 
92 responden, terdapat 17 responden $(18,5 \%)$ perokok dan 75 responden $(81,5 \%)$ tidak perokok. terdapat 18,6 responden berperilaku merokok yang memiliki konsep diri tinggi dan $18,2 \%$ responden berperilaku merokok yang memiliki konsep diri sedang. Hasil uji statistik dengan memakai uji chi-square di peroleh nilai $\mathrm{p}=1,000 \quad(\mathrm{p}>0,05)$, dengan demikian $\mathrm{H} 0$ ditolak. Hal ini menunjukan bahwa tidak ada hubungan antara konsep diri dengan perilaku merokok siswa dan siswi di SMP Negeri Satu Atap Toyado.

Tabel 1. Distribusi konsep diri siswa siswi Di SMP Negeri Satu Atap Toyado

\begin{tabular}{ccc}
\hline Konsep diri & Frekuensi & Persentase \\
\hline Sedang & 33 & 35,9 \\
Tinggi & 59 & 64,1 \\
\hline Total & 92 & 100,0 \\
\hline
\end{tabular}

Sumber: Data Primer, 2017

Tabel 2. Distribusi Perilaku Merokok siswa siswi di SMP Negeri Satu Atap Toyado

\begin{tabular}{ccc}
\hline Merokok & Frekuensi & Persentase \\
\hline Ya & 17 & 18,5 \\
Tidak & 75 & 81,5 \\
\hline Total & 92 & 100,0 \\
\hline
\end{tabular}

Sumber: Data Primer, 2017

Tabel 3. Distribusi hubungan konsep diri dengan perilaku merokok siswa siswi Di SMP Negeri Satu Atap Toyado

\begin{tabular}{ccccccc}
\hline & \multicolumn{4}{c}{ Konsep diri } & & \\
\cline { 2 - 5 } Perilaku & \multicolumn{2}{c}{ Sedang } & \multicolumn{2}{c}{ Tinggi } & Total & Nilai p \\
\cline { 2 - 5 } merokok & $\mathbf{n}$ & $\boldsymbol{\%}$ & $\mathbf{n}$ & $\mathbf{\%}$ & & \\
\hline Ya & 6 & 35,3 & 11 & 64,7 & 33 & \\
Tidak & 27 & 36,0 & 48 & 64,0 & 59 & 1,000 \\
\hline Jumlah & 33 & 35,9 & 59 & 64,1 & 92 & \\
\hline
\end{tabular}

\section{PEMBAHASAN}

\section{Konsep Diri}

Berdasarkan hasil penelitian didapatkan bahwa dari total 92 responden, terdapat 59 responden $(64,1 \%)$ terbanyak konsep diri tinggi dan 33 responden $(35,9 \%)$ terendah konsep diri sedang. Hal ini menunjukan bahwa semakin tinggi konsep diri siswa maka semakin tinggi pula kepercayaan dirinya. Sebaliknya jika semakin rendah konsep diri siswa, maka semakin rendah pula kepercayaan dirinya. Berarti semakin baik konsep diri yang dimiliki siswa akan membuat ia memiliki kepercayaan yang baik pula. Hal ini disebabkan terbentuknya kepercayaan diri pada siswa sebelumnya diawali dengan perkembangan konsep diri. Siswa yang menilai negatif dirinya sendiri akan merasa rendah diri. Ia merasa tidak mampu dan cenderung menghindari suatu pekerjaan yang sebenarnya dapat ia kerjakan. Begitu pula sebaliknya, siswa yang menilai positif dirinya, akan merasa percaya diri. Ia mampu memahami kelebihan yang dimiliki sehingga merasa yakin atas pekerjaan yang ia lakukan. Hal ini sesuai yang dikemukakan Anthony dalam M. Nur Ghufron dan Rini Risnawati (2012 bahwa terbentuknya kepercayaan diri pada seseorang diawali dengan perkembangan konsep diri yang diperoleh dalam pergaulannya dalam suatu kelompok ${ }^{(3)}$.

\section{Perilaku merokok}

Berdasarkan hasil penelitian didapatkan total 92 responden, terdapat $17 \quad(18,5 \%)$ perokok dan 75 (81,5\%) bukan perokok. Hal ini menunjukan bahwa perilaku siswa di SMP Negeri Satu Atap Toyado sudah baik dalam berperilaku namun masih ada sebagian siswa berperilaku buruk dalam merokok. Alasan yang didapatkan oleh peneliti sangat beragam salah satunya rasa penasan atau ingin coba- 
coba, dan di pengaruhi oleh teman sebaya. Tempat yang sering dipakai untuk melakukan perilaku merokok yaitu di tempat yang sering mereka jadikan titik kumpul bersama. Dalam sehari mereka menghabiskan 1-10 batang rokok dengan membelinya sendiri di toko atau warung. Perilaku merokok dilakukan di saat mereka dalam keadaan stress, kesal atau marah. Hal ini berarti bahwa masih ada sebagian siswa yang belum menyadari bahwa perilaku merokok tersebut tidak baik untuk kesehatan.

Seperti yang dikatakan oleh Mu'tadin (2002) "Saat ini perilaku merokok merupakan suatu gejala yang dapat kita lihat setiap hari di segala tempat seperti di jalanan, tempat keramaian, bus kota, Rumah Sakit, sekolah dan lain sebagainya. Semua orang mengetahui akan bahaya yang dapat ditimbulkan dari merokok, tetapi perilaku merokok tidak pernah surut dan tampaknya merupakan perilaku yang masih dapat ditolerir oleh masyarakat"(4).

\section{Hubungan konsep diri dengan perilaku merokok}

Berdasarkan hasil penelitian menunjukan bahwa terdapat 18,6 responden berperilaku merokok yang memiliki konsep diri tinggi dan 18,2\% responden berperilaku merokok yang memiliki konsep diri sedang. Hasil uji statistik dengan memakai uji chisquare di peroleh nilai $\mathrm{p}=1,000 \quad(\mathrm{p}>0,05)$, dengan demikian $\mathrm{HO}$ ditolak. Hal ini menunjukan bahwa tidak ada hubungan antara konsep diri dengan perilaku merokok siswa dan siswi di SMP Negeri Satu Atap Toyado.
Dalam penelitian yang dilakukan oleh Feldman (dalam Marselino, 2003) menyebutkan bahwa perilaku merokok berkaitan dengan konsep diri remaja ${ }^{(5)}$. Remaja perokok memiliki konsep diri yang mengandung beberapa unsur yang berbeda dengan remaja bukan perokok hal ini juga didukung oleh penelitian yang dilakukan oleh Botvin \& Mc.Allster (dalam Dina, 2001) menyebutkan bahwa salah satu faktor yang menyebabkan seseorang merokok adalah karena konsep diri yang negatif, jadi penelitian ini memperkuat teori sebelumnya karena seseorang yang mempunyai konsep diri positif dapat berpengaruh pada seluruh perilakunya. Satu tingkah laku akan selalu diikuti oleh konsekuensi tertentu,baik yang berasal dalam diri, luar diri ataupun keduanya. Konsekuensi tingkah laku akan menentukan apakah perilaku itu cenderung dipertahankan atau tidak. Dalam kosep diri terdapat dua dimensi yang relevan dalam berperilaku merokok, yaitu dimensi internal dan eksternal ${ }^{(6)}$.

\section{KESIMPULAN DAN SARAN}

Tidak ada hubungan antara konsep diri dengan perilaku merokok siswa. Disarankan agar siswa lebih memperkuat wadah atau organisasi ekstrakurikuler yang terkait upaya pencegahan terhadap bahaya perilaku perilaku merokok agar para siswa tidak melalukan perilaku merokok.

\section{DAFTAR PUSTAKA}

1. Aditama. (1992). Rokok dan kesehatan. Jakarta.

2. Kemenkes RI, 2013. Riset Kesehatan dasar. Jakarta. 
3. Risnawati, Rini dan M. Nur Ghufron. (2010). Teori-Teori Psikologi. Yogyakarta: Ar-Ruzz Media Group.

4. Mu'tadin. (2002). remaja dan rokok. Retrieved april senin, 2017, from http://www.epsikologi.com/remaja/050602

5. Marselino 2003. Hubungan Perasaan Rendah
Diti dan Intensitas Merokok pada Remaja Awal. Skripsi Fakultas Psikologi UI

6. Dina, R,Y. 2011. Sikap Remaja Terhadap Perilaku Merokok dan Gambaran Konsep Diri pada Remaja Perokok. Skripsi fakultas Psikologi Universitas Indonesia 